\title{
Strategie de căutare activă a cazurilor de boală celiacă la copiii simptomatici din România
}

\author{
Gabriela Leşanu ${ }^{1,2}$, Raluca Maria Vlad ${ }^{1,2}$, Cristina Becheanu ${ }^{1,2}$, \\ Iulia Florentina Țincu', Olivia Drăgnescu ${ }^{3}$, Alexandra Coroleucă', \\ Radu George Nicolaescu ${ }^{4}$, Daniela Păcurar ${ }^{1,2}$ \\ ${ }^{1}$ Spitalul Clinic de Urgenţă pentru Copii „Grigore Alexandrescu“, Bucureşti, România \\ ¿Universitatea de Medicină şi Farmacie „Carol Davila“, Bucureşti, România \\ IInstitutul Oncologic „Alexandru Trestioreanu“, Bucureşti, România \\ ${ }^{4}$ Institutul Clinic Fundeni, Bucureşti, România
}

\begin{abstract}
REZUMAT
Obiective. Medicii pediatri întâmpină provocări variate în diferite etape ale diagnosticului de boală celiacă (BC) la copil. Pe cine să testăm este în continuare un subiect disputat din cauza tabloului clinic heterogen. Scopul principal al studiului de față a fost de a identifica simptome sau asocieri de simptome care ar trebui să ridice suspiciunea şi să inițieze demersuri pentru diagnostic precoce de BC la copil.

Material şi metodă. Am efectuat un studiu prospectiv în cadrul secțiilor de Pediatrie ale Spitalului „Grigore Alexandrescu“, în perioada martie 2013-februarie 2014. Au fost incluşi 249 de copii cu simptome/semne sugestive pentru BC.

Rezultate. Au fost diagnosticați cu BC 11 pacienți (1 din 21 de pacienți evaluați). Pentru unul dintre 12,6; 16; 18; respectiv 18,5 dintre copiii cu diaree cronică, hipostatură, deficitul creşterii, dureri abdominale recurente şi constipație s-a stabilit diagnosticul de BC. Anumite asocieri de simptome au crescut acest risc: asocieri clasice (diaree cronică şi scădere în greutate), dar şi alte asocieri: dureri abdominale recurente şi scădere în greutate, constipație şi scădere în greutate, constipație şi anemie persistentă, refractară la tratament.

Concluzii. Căutarea activă în rândul pacienților cu simptome şi, mai ales, asocieri de simptome la risc de BC ar îmbunătăți depistarea şi ar creşte frecvența cu care este stabilit diagnosticul la copil.
\end{abstract}

Cuvinte cheie: boala celiacă, copil, căutare activă

\section{INTRODUCERE}

Câteva studii recente arată că incidența bolii celiace (BC) este încă în creştere (1-3). Deşi este un subiect de interes în rândul comunității medicale, un număr însemnat de cazuri rămân nediagnosticate. Pediatrul întâmpină dificultăți în diferite etape ale diagnosticului de boală celiacă la copil.

Prima provocare este reprezentată de identificarea cazurilor care necesită screening serologic. Pe cine să testăm este în continuare un subiect disputat datorită tabloului clinic heterogen. În plus, modalitatea de prezentare a acestor pacienți s-a schimbat semnificativ în ultimele decade: prevalența formei clasice a scăzut, pe când formele cu manifestări extraintestinale sau cu simptome digestive mai puțin sugestive sunt din ce în ce mai frecvente (4-8).
Statisticile arată o scădere a ponderei cazurilor diagnosticate în spital. O explicație ar putea rezulta din implicarea medicinei primare, a medicilor de familie în identificarea cazurilor simptomatice prin determinări serologice, urmate de diagnostic complet conform recomandărilor ESPGHAN (9), fără determinări histologice. În această situație, unele cazuri pot scăpa screeningului serologic din cauza prezentării clinice atipice.

O strategie eficientă de căutare activă a cazurilor este necesară pentru a scădea morbiditatea şi mortalitatea generate de BC netratată (10). Scopul principal al studiului de faţă a fost de a identifica simptome sau cele mai frecvente asocieri de simptome care ar trebui să ridice suspiciunea şi să iniţieze demersuri pentru diagnostic precoce de BC la copil. 


\section{MATERIAL ŞI METODĂ}

Am efectuat un studiu prospectiv în cadrul Spitalului Clinic de Urgență pentru Copii „Grigore Alexandrescu“, Bucureşti, care a inclus pacienți internați într-un interval de 12 luni, din martie 2013 până în februarie 2014. Toți pacienții spitalizați în secțiile de Pediatrie (Gastroenterologie, Pneumologie, Toxicologie şi Pediatrie Generală) au fost evaluați pentru a identifica acele cazuri cu semne şi simptome sugestive pentru BC.

Criteriul de includere a fost prezența semnelor şi simptomelor digestive şi extra-digestive cuprinse în criteriile de diagnostic pentru BC ale ESPGHAN din 2012 (9). Un grup de specialişti şi rezidenţi pediatri instruiți în acest sens a înregistrat datele pacienților într-un formular de includere (date demografice, istoricul alimentației, semne şi simptome, status nutrițional).

Pentru fiecare pacient s-au determinat anticorpii antitransglutaminază tisulară IgA (ATTG) şi nivelul IgA seric. Pentru pacienții cu deficit de IgA, s-a utilizat testare IgG-ATTG.

Diagnosticul de BC a fost stabilit conform criteriilor ESPGHAN revizuite, din 2012 (9). Biopsia intestinală a fost indicată şi s-a efectuat pentru toți pacienții cu ATTG pozitivi, dar cu nivel seric $<10$ ori normalul. S-a utilizat clasificarea MarshOberhuberand.

Pentru pacienții cu valori ATTG $>10$ ori normalul, s-au determinat anticorpii antiendomisium (EMA) şi s-a efectuat tipaj HLA DQ2/DQ8. În aceste cazuri, biopsia de mucoasă intestinală a fost opțională, după o discuție prealabilă cu părinții.

S-a efectuat o analiză statistică pe variabile individuale şi multiple pentru a identifica simptomele şi asocierile de simptome cu risc.

Studiul a fost aprobat de Comisia de Etică a Spitalului Clinic de Urgență pentru Copii „Grigore Alexandrescu“, Bucureşti. Un consimțământ informat a fost obținut de la aparținătorii fiecărui pacient eligibil.

\section{REZULTATE}

În perioada 1 martie 2013 - 28 februarie 2014 au fost internaţi 9.740 de pacienți în cele patru secții de Pediatrie ale Spitalului Clinic de Urgență pentru Copii „Grigore Alexandrescu“, Bucureşti (Gastroenterologie, Pneumologie, Toxicologie şi Pediatrie Generală). Dintre aceștia, au fost selectați şi incluşi în studiu 249 de copii care au prezentat simptome/semne sugestive pentru BC conform ghidului ESPGHAN (9): 124 de fete, 125 de băieți, vârstă medie 5 ani şi 4 luni. Tabelul 1 ilustrează tabloul pacienților la prezentare.

TABELUL 1. Semne şi simptome cu risc crescut pentru BC la pacienții incluşi în studiu

\begin{tabular}{|l|c|c|}
\hline Semne/simptome & Nr. cazuri & Procent \\
\hline Diaree cronică & 63 & 25,3 \\
\hline Eşecul creşterii & 147 & 59 \\
\hline Hipostatură & 49 & 19,6 \\
\hline Scădere în greutate & 18 & 7,2 \\
\hline Distensie abdominală/flatulență & 23 & 9,2 \\
\hline Constipație & 37 & 14,8 \\
\hline Dureri abdominale recurente & 51 & 20,4 \\
\hline Vărsături recurente & 12 & 4,8 \\
\hline Anorexie & 45 & 18 \\
\hline Stomatită recurentă & 5 & 2 \\
\hline Fatigabilitate & 10 & 4 \\
\hline Tulburări de comportament & 2 & 0,8 \\
\hline Pubertate întârziată & 2 & 0,8 \\
\hline Citoliză hepatică & 14 & 5,6 \\
\hline Anemie feriprivă refractară & 8 & 3,2 \\
\hline
\end{tabular}

Opt pacienți au fost diagnosticați cu deficit de IgA; la aceştia s-au determinat ATTG-IgG. Unsprezece pacienţi au avut ATTG-IgA pozitivi şi 3 dintre pacienții cu deficit de IgA au prezentat niveluri crescute de ATTG-IgG. Dintre cei 14 pacienți cu ATTG pozitivi (IgA/IgG), 2 au fost pierduți din urmărire (nu s-au prezentat pentru continuarea investigațiilor conform protocolului).

Patru pacienți au avut valori ATTG $<10$ ori normalul şi examenul histologic a evidenţiat modificări clasificate în categoria Marsh 3, confirmându-se astfel diagnosticul de BC. Pentru aceşti 4 pacienți s-a efectuat şi tipaj HLA: toți au fost HLA DQ2 pozitivi.

Opt pacienţi au avut valori ATTG $>10$ ori normalul. Pentru toți $8 \mathrm{~s}-\mathrm{a}$ efectuat testare genetică: unul dintre ei s-a dovedit HLA DQ2/DQ8 negativ, ceea ce a infirmat diagnosticul de BC (ATTG fals pozitivi); ceilalți 7 au fost HLA DQ2 pozitivi (4 pacienți), HLA DQ8 pozitivi (2 pacienți) sau HLA DQ2 şi DQ8 pozitivi (1 pacient). Pentru toți aceşti 7 pacienți s-au dozat EMA care au avut valori pozitive. Astfel, coroborând aceste determinări cu testarea HLA pozitivă, a fost confirmat diagnosticul de BC. Pentru 3 dintre pacienții cu valori ATTG mari s-a efectuat şi biopsie intestinală care a detectat leziuni Marsh 3.

Au fost diagnosticaţi cu BC 11 pacienți ( 9 fete şi 2 băieți), reprezentând 1 din 21 de pacienți evaluați pentru semne/simptome la risc. Vârsta medie la diagnostic a fost 4 ani şi 1 lună \pm 1 an şi 7 luni.

Vârsta medie la care s-a introdus glutenul a fost 7,3 luni, variind între 4 şi 12 luni. 
Cele mai frecvente semne/simptome la prezentarea pacienților celiaci au fost: eşecul creşterii, diaree cronică, constipație şi dureri abdominale recurente (Tabelul 2).

TABELUL 2. Semne şi simptome la prezentarea pacienților cu BC

\begin{tabular}{|l|c|c|}
\hline Semne/simptome & Nr. cazuri & Procent \\
\hline Eşecul creşterii & 8 & 72 \\
\hline Diaree cronică & 5 & 45,5 \\
\hline Constipație & 4 & 36,4 \\
\hline Dureri abdominale recurente & 4 & 36,4 \\
\hline Hipostatură & 3 & 27,3 \\
\hline Scădere în greutate & 3 & 27,3 \\
\hline Vărsături recurente & 3 & 27,3 \\
\hline Distensie abdominală/flatulență & 2 & 18,2 \\
\hline Anorexie & 1 & 9,1 \\
\hline Tulburări de comportament & 1 & 9,1 \\
\hline Citoliză hepatică & 1 & 9,1 \\
\hline Anemie feriprivă refractară & 1 & 9,1 \\
\hline
\end{tabular}

Pentru unul din 12,$6 ; 16 ; 18$ dintre copiii cu diaree cronică, hipostatură, respectiv deficitul creşterii, dar şi pentru unul din 18,5 cu dureri abdominale recurente şi respectiv constipație, s-a stabilit diagnosticul de BC. Anumite asocieri de simptome s-au dovedit a asocia risc crescut de BC (Tabelul 3).

TABELUL 3. Asocieri de simptome şi riscul de BC

\begin{tabular}{|l|c|c|c|}
\hline Asocieri de simptome & OR & $\mathbf{9 5 \%} \mathbf{C l}$ & $\mathbf{P}$ \\
\hline $\begin{array}{l}\text { Dureri abdominale recurente şi } \\
\text { scădere în greutate }\end{array}$ & 29,3 & $5,1-168,8$ & 0,001 \\
\hline Diaree cronică şi scădere în greutate & 27,4 & $14,4-52,1$ & 0,003 \\
\hline Diaree cronică şi eşecul creşterii & 8,6 & $2,4-30,6$ & 0,003 \\
\hline Constipație şi scădere în greutate & 26,2 & $3,3-207,7$ & 0,01 \\
\hline Constipație şi anemie refractară & 24,8 & $13,5-45,5$ & 0,04 \\
\hline
\end{tabular}

\section{DISCUȚII}

Din 249 de pacienţi (vârstă medie: 5 ani şi 4 luni, variind între 8 luni şi 17 ani) care s-au prezentat cu simptome/semne compatibile cu diagnosticul de BC, 14 pacienți au avut ATTG pozitivi (vârstă medie: 4 ani, variind între 1 an şi 11 luni şi 8 ani). Deşi am evaluat pacienţi de toate vârstele, majoritatea $(71,4 \%)$ dintre copiii cu serologie celiacă pozitivă au fost mai mici de 6 ani.

$\mathrm{BC}$ a fost diagnosticată la 1 din 21 de pacienți care s-au prezentat cu simptome sugestive. Copiii diagnosticați cu $\mathrm{BC}(\mathrm{n}=11)$ au avut vârsta medie de 4 ani şi 1 lună, variind de la 1 an şi 11 luni până la 6 ani şi 11 luni. Majoritatea (9 cazuri) au fost fete, deşi au fost testați băieți şi fete în procente similare.

Copiii acestei cohorte s-au născut între 1996 şi 2012. Pentru majoritatea, glutenul a fost introdus mai târziu, conform recomandărilor ESPGHAN la momentul respectiv; acestea au fost modificate deabia în 2008 (11), când s-a recomandat ca glutenul să fie introdus progresiv între 4 şi 7 luni. În studiul nostru, la pacienții celiaci glutenul a fost introdus între 6 şi 12 luni, cu o singură excepție (4 luni). Introducerea tardivă a glutenului se asociază cu întârzierea debutului simptomatologiei; aceasta este o observație veche în literatură, dar este susținută şi de studii recente (12).

Mai puțin de jumătate dintre pacienții celiaci s-au prezentat cu tablou clasic (diaree cronică şi eşecul creşterii), nici unul cu criză celiacă sau malnutriție severă, tipuri de prezentare cu care eram obişnuiți până în urmă cu câțiva ani (13). Ceilalți au asociat: dureri abdominale recurente, constipaţie, eşecul creşterii şi un pacient cu citoliză hepatică. Formele mai uşoare, mono sau oligosimptomatice au devenit mai frecvente şi în experiența noastră, similar cu raportări din alte țări europene $(7,8,14)$.

Din 63 de pacienți (cu vârste cuprinse între 7 luni şi 15 ani) care s-au prezentat cu diaree cronică, $5(7,9 \%)$ au fost celiaci (cu vârste cuprinse între 1 an şi 11 luni şi 4 ani şi 8 luni). Aşadar, diareea cronică este în continuare un simptom caracteristic BC la copilul mic, studii publicate recent confirmând această constatare $(15,16)$. Diareea cronică severă, cu steatoree este în prezent raportată rar, cel mai adesea pacienții adresându-se medicului pentru diaree intermitentă, episoade recurente care ar trebui să ridice în mintea clinicianului suspiciunea şi să determine iniţierea screeningului serologic pentru BC. Riscul de BC este mai mare când diareea cronică se asociază cu scădere în greutate.

În urmă cu două decade, durerile abdominale recurente erau rareori asociate cu BC şi pentru acest tablou clinic nu se justifică screeningul serologic (17). Ulterior în țările vest europene, America de Nord (6,18-20) şi alte regiuni geografice $(21,22)$, această formă de prezentare a devenit foarte frecventă, ca unică manifestare sau în asociere cu alte simptome. În studiul lui Khatib a fost evaluat un grup de celiaci diagnosticați recent (2003-2013) în Statele Unite, iar durerile abdominale recurente au fost raportate în procent mai mare decât diareea cronică, fiind cel mai frecvent simptom digestiv (23). În studiul de față, 7,8\% dintre pacienții cu dureri abdominale recurente au fost celiaci. Riscul este şi mai mare când acest simptom se asociază cu scădere în greutate.

Constipația a fost raportată în urmă cu mulţi ani la pacienții celiaci, dar frecvența diferă în literatură. Studiul multicentric TEDDY a arătat că la copiii simptomatici constipația este la fel de frecventă 
ca diareea (16). Indicația de screening serologic pentru BC la pacienții cu constipație reprezintă încă o controversă, nefiind recomandată în unele studii (24), dar considerată necesară de altele (25). Dintre 37 de copii cu constipație, 4 (10,8\%) au fost celiaci. Studiul de față sugerează că riscul de BC creşte atunci când există asocierea constipaţie-alte semne/simptome (dureri abdominale recurente, scădere în greutate, anemie feriprivă refractară la tratament).

Din 147 de pacienți cu eşecul creşterii, 8 au fost diagnosticaţi cu BC, 6 prezentând simptome asociate, dar pentru doi dintre ei aceasta fiind singura manifestare.

Având în vedere că prevalența $\mathrm{BC}$ este crescută, dar mulți dintre pacienți rămân nediagnosticați deoarece prezintă manifestări fruste, se discută în ultima vreme utilitatea screeningului (26). O lucrare recentă a analizat $\mathrm{BC}$ din perspectiva criteriilor Organizației Mondiale a Sănătății pentru screening de masă, iar autorii au concluzionat că dovezile curente nu sunt suficiente pentru a se recomanda screening populațional, dar căutarea activă ar fi o măsură adecvată (27). Strategia de căutare activă pe care am utilizat-o în prezentul studiu a condus la o creş- tere a ratei de diagnostic pentru $\mathrm{BC}$ în departamentele de Pediatrie ale spitalului nostru de la 0,28 de pacienți cu BC la 1.000 de pacienți spitalizați în anul precedent, la 1,13 la 1.000 în anul studiului.

\section{CONCLUZII}

Prevalența BC la pacienții simptomatici a fost de $4,4 \%$.

Diareea cronică este încă o formă de prezentare frecventă a pacienților cu BC, mai ales la vârstă mică, dar aproape la fel de frecvente sunt durerile abdominale recurente sau constipaţia, aşadar screeningul serologic celiac ar trebui luat în considerare şi pentru copiii cu aceste simptome.

Anumite asocieri de simptome cresc riscul de $\mathrm{BC}$ : asocieri clasice (diaree cronică şi scădere în greutate), dar şi alte asocieri (dureri abdominale recurente şi scădere în greutate, constipație şi scădere în greutate, constipație şi anemie persistentă, refractară la tratament).

Căutarea activă în rândul pacienților cu simptome şi, mai ales, asocieri de simptome cu risc crescut de BC ar îmbunătăţi depistarea şi ar creşte frecvența cu care este stabilit diagnosticul la copil. 